\title{
Alopécia Permanente Pós-Quimioterapia com Resposta Favorável ao Minoxidil Tópico
}

\author{
Eugénia Matos Pires ${ }^{1}$, Rita Ramos Pinheiro', André Lencastre ${ }^{1,2}$ \\ 'Dermatology and Venereology Department, Centro Hospitalar de Lisboa Central, Hospital de Santo António dos Capuchos, Lisbon, \\ Portugal \\ ${ }^{2}$ Dermatology and Venereology Department, Hospital da Luz, Lisbon, Portugal
}

RESUMO - A alopécia permanente pós-quimioterapia é um efeito adverso raro, classicamente associada a altas doses de quimioterapia sistémica com busulfan para transplante de medula óssea. Recentemente têm sido descritos casos de alopécia permanente pós-quimioterapia em doentes submetidos a quimioterapia sistémica com taxanos no carcinoma da mama. Na revisão da literatura não existem orientações terapêuticas consistentes para esta entidade com impacto importante na qualidade de vida dos doentes. Descreve-se o caso de uma doente de 38 anos que desenvolveu alopecia inaugural e permanente após quimioterapia com taxanos (docetaxel) para carcinoma da mama, com 2 anos de evolução à data da observação. Após 6 meses de tratamento tópico com solução de minoxidil 5\%, em regime bidiário, assistiu-se a resposta clínica favorável. Os autores revêm o provável mecanismo patológico da alopécia permanente pós-quimioterapia, bem como os efeitos do minoxidil tópico no ciclo do cabelo, por forma a sustentar este fármaco como opção terapêutica a considerar neste tipo de alopecia.

PALAVRAS-CHAVE - Alopecia/induzida quimicamente; Alopecia/tratamento Minoxidil; Taxanos.

\section{Case of Permanent Chemotherapy-Induced Alopecia with Response to Topical Minoxidil}

ABSTRACT - Permanent chemotherapy-induced alopecia is uncommon and has primarily been reported after high-dose busulfan chemotherapy in bone marrow transplant patients. Nevertheless, cases of PCIA, after taxane chemotherapy protocols for breast cancer, have been recently described. Despite the impact on patients' quality of life, no consistently effective treatment has been previously described for taxane-associated permanent chemotherapy-induced alopecia. We herein report a case of a 38-year-old woman who presented inaugural and persistent hair loss after completion of adjuvant chemotherapy with taxane (docetaxel) for breast carcinoma, 2 years before the present observation. After 6 months of continuous therapy with topical minoxidil solution 5\%, twice daily, significant hair regrowth was noted. We discuss the pathophysiology of permanent chemotherapy-induced alopecia and the effects of minoxidil on hair growth, in order to substantiate topical minoxidil 5\% as an option to consider in the therapeutic approach for permanent chemotherapy-induced alopecia.

KEYWORDS - Alopecia/chemically induced; Alopecia/therapy; Minoxidil; Taxoids.

\section{INTRODUCTION}

Chemotherapy induced alopecia is a very common side effect of several cancer treatments and is typically reversible within 6 months.' Permanent chemotherapy-induced alopecia (PCIA) is uncommon, ${ }^{1}$ and has primarily been reported with busulfan and high-dose cyclophosphamide conditioning regimens, given before bone marrow transplantation. ${ }^{2}$ Nevertheless, cases of PCIA after taxane chemotherapy protocols for breast cancer have been recently described, ${ }^{3-5}$ showing that permanent alopecia is not solely linked to high-dose chemotherapy regimens.

No consistently effective treatment has previously been described for taxane-associated PCIA. Topical minoxil has been used in some reports but a refractory course was typically described. ${ }^{3,5}$

\section{CASE REPORT}

We report a case of a 38-year-old caucasian woman with
Correspondência: Eugénia Matos Pires

Hospital dos Capuchos, Serviço de DermatoVenereologia

Alameda Santo António dos Capuchos - 1169-050 Lisboa, Portugal

E-mail: eugeniampp@gmail.com
Recebido/Received

02 Abril/April 2017

Aceite/Accepted

10 Junho/June 2017 


\section{Caso Clínico}

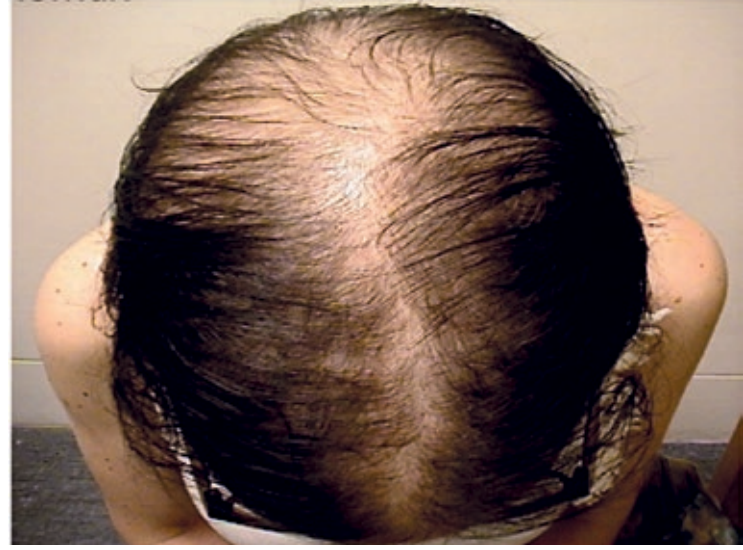

Figure 1 a = Alopecia inaugural after taxane chemotherapy.

a history of breast carcinoma who presented inaugural and persistent hair loss after completion of adjuvant chemotherapy, 2 years before the present observation. A regimen including docetaxel, adriamycin and cyclophosphamide had been followed. Her clinical history was otherwise negative, including for androgenetic alopecia (AGA) and she was currently having no other medication. Clinical examination showed a diffuse alopecia with characteristics of a female pattern androgenetic hair loss (Ludwig II, Sinclair IV) (Fig. 1a). Trichoscopy revealed hair shaft diameter variability, with a significant proportion of vellus hairs (Fig. 1b). The remaining examination was otherwise normal, namely the nails. Laboratory analysis including hormonal levels, VDRL and autoantibodies were in the normal range. Treatment with topical minoxidil solution 5\%, twice daily, produced some improvement. After 6 months of continuous therapy, significant regrowth of the hair was noted both clinically (Fig. 2a) and dermoscopically (Fig. 2 b) with adequate patient satisfaction.

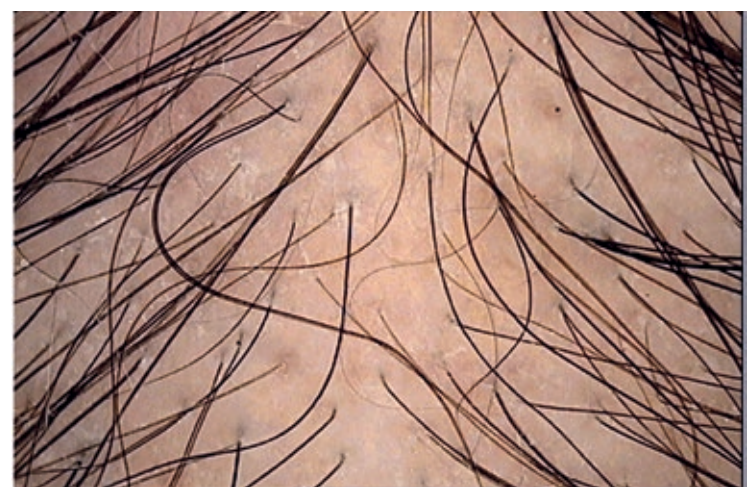

Figure $1 \mathbf{b}$ - Tricoscopy corresponding to Figure $1 \mathrm{a}$ : hair shaft diameter variability, with a significant proportion of vellus hairs.

\section{DISCUSSION}

The risk of PCIA is related to several factors, including the chemotherapeutic agent. We believe that docetaxel was responsible for the $\mathrm{PCIA}$ in this case, as already suggested

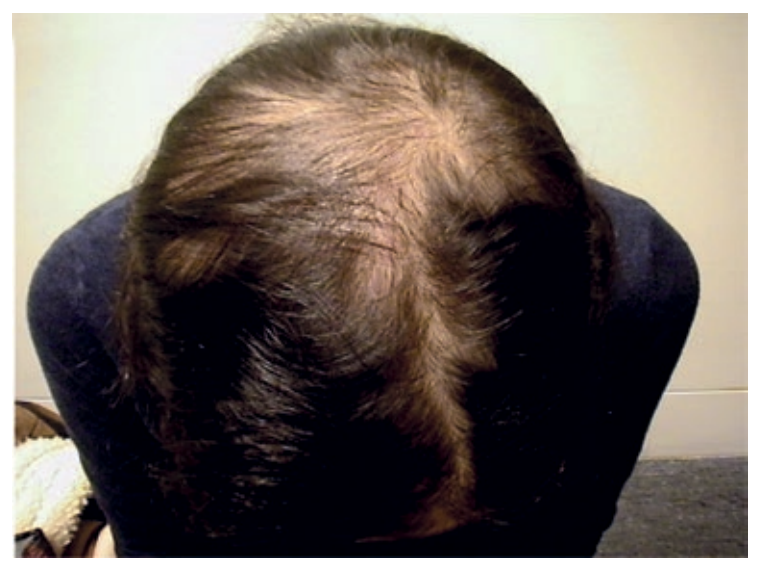

Figure 2a - Clinical improvment six months after treatment with topical minoxidil 5\% twice daily.

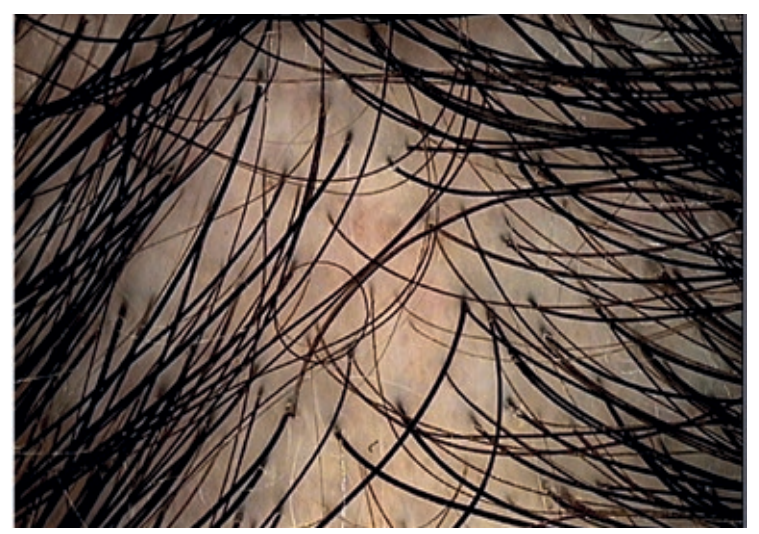

Figure $\mathbf{2} \mathbf{b}$ - Tricoscopy corresponding to Figure 2a: significant regrowth of the hair; less hair shaft diameter variability and fewer vellus hairs.

by other case reports. ${ }^{3-5}$ The other two agents in this patient's protocol, typically associated with reversible alopecia, ${ }^{6}$ may also have contributed to PCIA.

The pathophysiology of PCIA remains to be elucidated. Currently, however, it seems that chemotherapeutic agents share proapoptotic pathways (mainly mediated by p53) that selectively target growing cells, and consequently prominently affect the highly proliferative hair-matrix keratinocytes of anagen hair follicles. ${ }^{7,8}$ This leads to hair-cycle abnormalities, often reversible within 6 weeks after cessation of chemotherapy. Hair follicle epithelial stem cells are a vital progenitor for epithelial lineages within the follicle. ${ }^{7}$ Throughout evolution these cells have developed molecular mechanisms of chemoresistance to apoptosis which will allow the regeneration of follicles several times over throughout life, even after great injury from chemotherapy. Nevertheless, it seems that the same resistant hair follicle stem cells have an increased sensitivity to select agents, such as taxanes. These agents may have the ability to induce stem-cell damage leading to $\mathrm{PCIA}{ }^{7}$ It is also believed that certain genetic polymorphisms determine individual susceptibility to 
cytotoxic effects of chemotherapy. ${ }^{9}$ Therefore, $\mathrm{PCIA}$ is likely multifactorial: the degree of alopecia induced by chemotherapeutic agents may depend on dose, administration regimen, patient age, comorbidities, nutritional and hormonal status. ${ }^{7}$ Overall, beyond drug-related specific hair follicle toxicity, many other individual factors are implicated, also shared by other forms of non-scarring alopecia, such as AGA.

PCIA and AGA have different etiologies. ${ }^{8}$ However, clinical features of PCIA seem strikingly similar to that of severe AGA. ${ }^{5}$ The histological picture of taxane-related permanent alopecia is consistent in all published reports. ${ }^{3-5}$

Although the mode of action remains to be fully understood, topical minoxidil is known to stimulate hair growth, and has proven efficacy on AGA. ${ }^{10}$ In a review, Messenger and Rundegren ${ }^{10}$ suggested that minoxidil acts mainly on the hair cycle, causing premature termination of telogen, prolonging anagen. They also postulate that irrespective the mechanism of action, minoxidil must have effects on cell function: cell growth, collagen and prostaglandin synthesis, and stimulation of VEGF synthesis. In addition to the effects on the hair cycle, minoxidil action on cell function may have some benefit on the hair follicle stem cells, which may explain improved hair regrowth after PCIA observed in our patient,.

Regarding the current knowledge of PCIA mechanism and the effects of minoxidil on hair growth, we observed a significant improvement of the patient's alopecia, contrasting with the usual refractory course described in PCIA. Topical minoxidil 5\% twice a day may be a safe option to be considered in the therapeutic approach of these patients.

Conflitos de interesse: Os autores declaram não possuir conflitos de interesse.

Suporte financeiro: $O$ presente trabalho não foi suportado por nenhum subsídio ou bolsa.

Confidencialidade dos dados: Os autores declaram ter seguido os protocolos do seu centro de trabalho acerca da publicação dos dados de doentes.

Protecção de pessoas e animais: Os autores declaram que os procedimentos seguidos estavam de acordo com os regulamentos estabelecidos pelos responsáveis da Comissão de Investigação Clínica e Ética e de acordo com a Declaração de Helsínquia da Associação Médica Mundial

Conflicts of interest: The authors have no conflicts of interest to declare.

Financing Support: This work has not received any contribution, grant or scholarship.

Confidentiality of data: The authors declare that they have followed the protocols of their work center on the publication of data from patients.

Protection of human and animal subjects: The authors declare that the procedures followed were in accordance with the regulations of the relevant clinical research ethics committee and with those of the Code of Ethics of the World Medical Association (Declaration of Helsinki).

\section{REFERENCES}

1. Chon SY, Champion RW, Geddes ER, Rashid RM. Chemotherapy-induced alopecia. J Am Acad Dermatol. 2012; 67:37-47.

2. Machado M, Moreb JS, Khan SA. Six cases of permanent alopecia after various conditioning regimens commonly used in hematopoietic stem cell transplantation. Bone Marrow Transplant. 2007; 40:979-82.

3. Prevezas C, Matard B, Pinquier L, Reygagne P. Irreversible and severe alopecia following docetaxel or paclitaxel cytotoxic therapy for breast cancer. Br J Dermatol. 2009; 160:883-5.

4. Tallon B, Blanchard E, Goldberg LJ. Permanent chemotherapy-induced alopecia: case report and review of the literature. J Am Acad Dermatol. 2010; 63:333-6.

5. Kluger N, Jacot W, Frouin E, Rigau V, Poujol S, Dereure $O$ et al. Permanent scalp alopecia related to breast cancer chemotherapy by sequential fluorouracil/epirubicin/ cyclophosphamide (FEC) and docetaxel: a prospective study of 20 patients. Ann Oncol. 2012; 23:2879-84.

6. De Jonge ME, Mathôt RA, Dalesio O, Huitema ADR, S Rodenhuis $\mathrm{S}$ Beijnen JH. Relationship between irreversible alopecia and exposure to cyclophosphamide, thiotepa and carboplatin (CTC) in high-dose chemotherapy. Bone Marrow Transplant. 2002; 30:593-7.

7. Paus R, Haslam IS, Sharov AA, Botchkarev VA. Pathobiology of chemotherapy-induced hair loss. Lancet Oncol. 2013; 14:50-9.

8. Santos Z, Avic P, Hamblin H. Drug discovery for alopecia: gone today, hair tomorrow. Expert Opin Drug Discov. 2015; 10: 269-92.

9. Frederiks CN, Lam SW, Guchelaar HJ, Boven E. Genetic polymorphisms and paclitaxel- or docetaxel-induced toxicities: A systematic review. Cancer Treat Rev. 2015; 41:935-50.

10. Messenger AG, Rundegren J. Minoxidil: mechanisms of action on hair growth. Br J Dermatol. 2004; 150:18694. 